\title{
Abrupt transition of the northwestern Black Sea shelf ecosystem from a eutrophic to an alternative pristine state
}

\author{
Temel Oguz ${ }^{1, *}$, Violeta Velikova $^{2}$ \\ ${ }^{1}$ Institute of Marine Sciences, Middle East Technical University, PO Box 28, Erdemli 33731, Mersin, Turkey \\ ${ }^{2}$ Permanent Secretariat Commission on the Protection of the Black Sea Against Pollution, Istanbul, Turkey
}

\begin{abstract}
Long-term (1960-2005) ecological data were used to identify a regime shift in the northwestern Black Sea shelf and to assess whether it has recovered from its former eutrophic state. Following the collapse of fish stocks and the population explosion of the ctenophore Mnemiopsis leidyi between 1988 and 1991, anthropogenic $\mathrm{P}_{-} \mathrm{PO}_{4}$ loads from the River Danube dropped strongly in 1992-1993. This decline in $\mathrm{P}_{-} \mathrm{PO}_{4}$ levels was caused by reductions in fertilizer use and emissions from land-based point sources during the economic recession of former Eastern Bloc countries, as well as by the low discharge rate of the River Danube. Commencing in 1993, the phosphate limitation apparently maintained a low-energy, inefficient food web dominated by the dinoflagellate Noctiluca scintillans and jellyfish, and relatively low levels of phytoplankton, bacterioplankton, mesozooplankton and fish. This 'post-eutrophication' regime was markedly different from the classical phytoplankton-mesozooplankton-fish chain of the similarly low nutrient 'pre-eutrophication' regime prior to 1970. Therefore it appears that the food web can attain 2 alternative regimes during periods of low productivity of the ecosystem. The post-eutrophication state cannot be considered as a major improvement or restoration of the northwestern coastal ecosystem.
\end{abstract}

KEY WORDS: Black Sea · Coastal eutrophication - Nutrient limitation · Alternative community states · Regime shift · Trophic control

\section{INTRODUCTION}

The Black Sea has been one of the most polluted and mismanaged semi-enclosed seas in the world. The extensive pollutant loads discharged primarily by the River Danube, together with over-fishing, dumping of toxic wastes, intense shipping, mineral exploitation, introduction of non-native species, damming of inflowing rivers, and climatic variation have led to severe environmental degradation since 1970 (Sapojnikov 1992, Mee 1992, 2006, Vinogradova \& Velikova 1992, Zaitsev 1992, Zaitsev \& Mamaev 1997, Daskalov 2002, Kideys 2002, Sorokin 2002, Cociasu \& Popa 2005, Yunev et al. 2007). Vast amounts of dead plants and animals have often been encountered in the northwest, along the Romanian and Ukrainian coasts. Between 1973 and 1990, despite losses estimated at 60 million tons of benthic animals including 5 million tons of fish, pollution and eutrophication control measures were not implemented (Mee et al. 2005).

A general consensus of recent assessments of changing environmental conditions of the Black Sea is that the northwestern shelf (NWS) has improved in the last decade due to decreasing nutrient loads from the rivers (Parr et al. 2005, GEF-UNDP 2006, TDA 2007, BSC 2008). There have been fewer algal blooms, lower algal biomass, increasing plankton biodiversity, decreasing opportunistic and gelatinous species, and reappearance of cladocerans and copepods (Shiganova et al. 2008).

Ecological regime shifts denote abrupt changes that result in reorganization of the structure and function of ecosystems from one to another contrasting, persistent state (deYoung et al. 2008). Regime shifts driven syner- 
gistically by climate-induced changes, eutrophication, and overfishing have been documented in many marine ecosystems. Concurrent with the apparent regime shift in the Black Sea, other shifts occurred in the Baltic Sea (Möllmann et al. 2009), northwest Atlantic (Choi et al. 2005), northeast Atlantic (Beaugrand et al. 2008), North Sea (Weijerman et al. 2005), and north Pacific (Hare \& Mantua 2000). Characteristics of the Black Sea basin-scale regime shift have been studied by Daskalov et al. (2007), Oguz \& Gilbert (2007), and Oguz et al. (2008a).

Measures taken at many coastal ecosystems, such as in the Baltic Sea (Hanninen et al. 2000, Lysiak-Pastuszak et al. 2004, Yurkovskis 2004), United States coastal ecosystems (Nixon et al. 1996, Scavia \& Bricker 2006), and the Dutch Wadden Sea (Philippart et al. 2007), did not successfully alleviate eutrophication. Even lake and pond ecosystems with a relatively simple food web structure and a faster response to external controls may not achieve a transition to a healthier state after the reduction of nutrient loads or may have a delayed response depending on the internal feedback mechanisms (Genkai-Kato \& Carpenter 2005, Ibelings et al. 2007). Here, we offer a novel viewpoint on the post-eutrophication ecological state of the northwestern Black Sea. We document an ecological regime shift that transformed the highly productive and eutrophic coastal ecosystem into a less productive but degraded state during the early 1990s. We assert that it differs considerably from the pristine state and does not truly represent a recovery.

\section{MATERIALS AND METHODS}

Study area. The northwestern Black Sea shelf is the triangular region shallower than $100 \mathrm{~m}$ between 42.5 and $46.5^{\circ} \mathrm{N}$ latitude and 28 and $33^{\circ} \mathrm{E}$ longitude (Fig. 1). It covers roughly $30 \%$ of the total Black Sea area and $94 \%$ of the overall shelf region around the basin. Its apex is located near Odessa in the north and the base extends along the shelf-break topography (e.g. $100 \mathrm{~m}$ depth) from the Bulgarian coast to the southern tip of Crimea (Ukraine). The topographic slope in the southwest makes the shelf progressively narrower towards the Bulgarian coast (Fig. 1). This feature and mesoscale exchanges between the shelf and deep basin over the broad topographic slope zone (Korotaev et al. 2003, Yankovsky et al. 2004) reduce eutrophication southward. The shelf lying roughly north of $\sim 45^{\circ} \mathrm{N}$ receives considerable fresh water and nutrient discharges from the Danube, Dniepr, Dniestr and Bug Rivers, and thus offers a more eutrophic and ecologically complex system.

Data sets. The long-term (1960 to 2005) data employed in the current study consists of annual mean concentrations of dissolved inorganic nutrients and biomass of phytoplankton, non-gelatinous and gelatinous zooplankton groups, or species measured at regularly monitored stations of the Ukrainian, Romanian and Bulgarian shelves (Fig. 1) as well as fish catches. This analysis is therefore limited to the

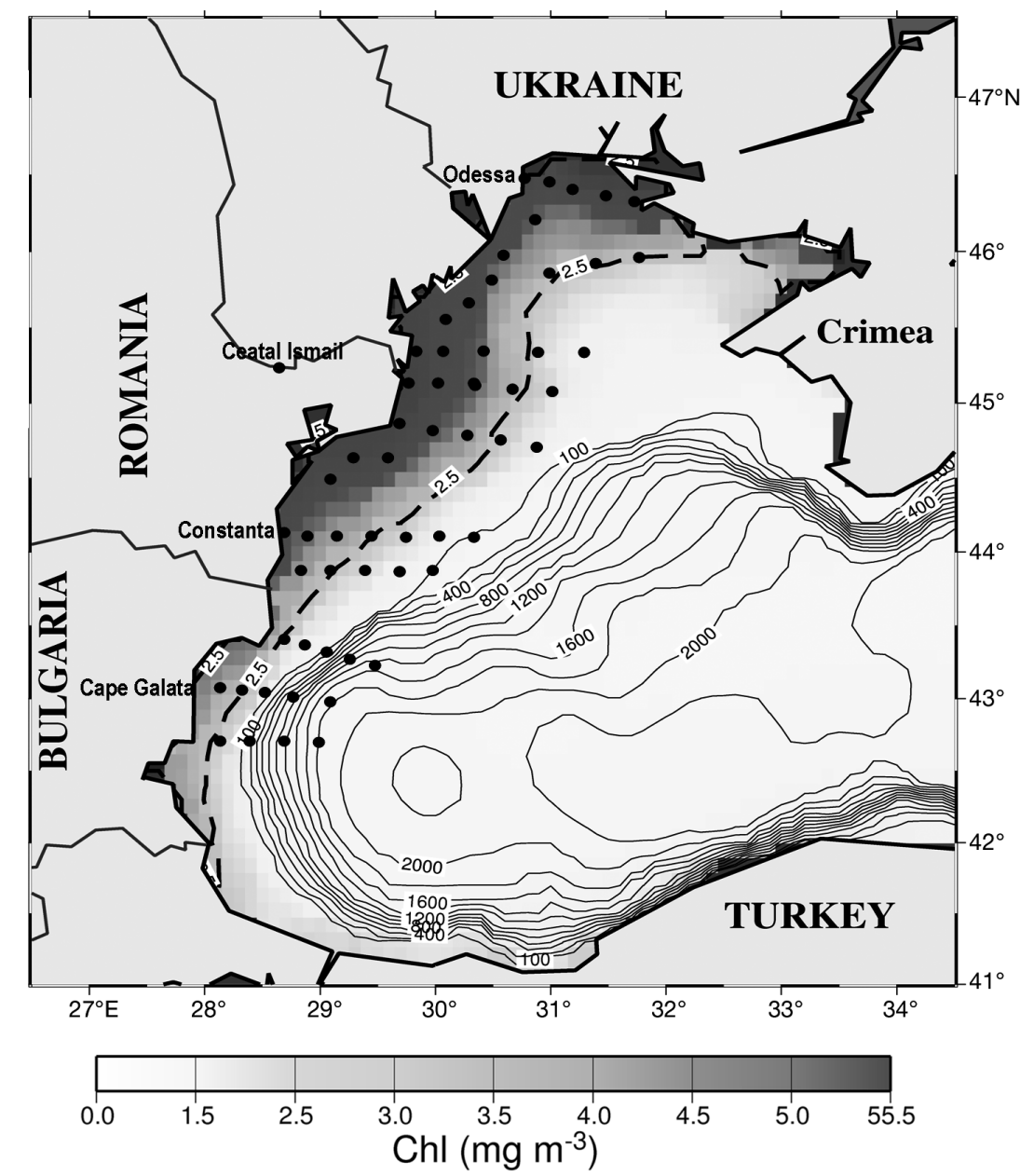

Fig. 1. Main geographic and topographic features of the northwestern Black Sea and the station network of long-term regular measurement sites $(\bullet)$ in the Bulgarian, Romanian and western Ukrainian shelves. Depth contours in $\mathrm{m}$. The black line represents the $2.5 \mathrm{~g} \mathrm{~m}^{-3}$ contour of the 1998-2008 mean surface chlorophyll concentration that separates the more productive inner shelf zone and less productive outer shelf and deep basin (shown in white). The chlorophyll data are retrieved from $9 \mathrm{~km}$ monthly Sea-viewing Wide Field-ofview Sensor (SeaWiFS) products provided by http://reason.gsfc.nasa.gov/ OPS/Giovanni/ocean.seawifs.2.shtml 
pelagic ecosystem. Parameters, measurement periods, and data sources are listed in Table 1. The complete data set consists mostly of individual scientific contributions to the assessment of the state of Black Sea environment report (BSC, 2008) for the Secretariat of the Commission on the Protection of the Black Sea against Pollution (the Black Sea Commission, BSC). The individual data sets represent either specific measurements made at a particular station or regional averages of measurements made at several stations. They have been computed from available monthly or seasonal measurements depending on the parameter and institution that performed the measurements. Regional averaging offers a more general representation of the ecological conditions and applies mostly to the Ukrainian time series data (see Table 1). We conclude that a spatially uniform distribution of an $11 \mathrm{yr}$ (1998-2008) average surface chlorophyll concentration (Fig. 1) justifies the use of data from multiple stations for some parameters and a single station for others. A chlorophyll concentration of $2.5 \mathrm{mg} \mathrm{m}^{-3}$ (Fig. 1) splits the shelf region into 2 distinct zones in terms of their capacity for biological production. The data sets used in the present study represent the more productive inner zone.
The annual mean sea surface temperature (SST) anomaly data were constructed from monthly measurements made at Odessa from 1950 to 1994 (Belevich \& Orlova 1997), and at Constanta from 1980 to 2005 (Cociasu et al. 2008). The River Danube discharge anomaly for 1950 to 2005 was obtained from long-term monthly discharge measurements made at Ceatal Ismail (Cociasu et al. 2008), which is located upstream of the 3 branches of the River Danube (Fig. 1).

The long-term annual mean data sets for the dissolved inorganic nutrient (DIN) and silicate $\left(\mathrm{SiO}_{4}\right)$ concentrations are limited to measurements at the Romanian coastal monthly monitoring site at 3 nautical miles offshore of Constanta (Cociasu et al. 2008). These offer the only long time series for $\mathrm{SiO}_{4}$ between 1960 and 2005 and for DIN $\left(=\mathrm{NO}_{3}+\mathrm{NO}_{2}+\mathrm{NH}_{4}\right)$ between 1981 and 2005. The Constanta DIN time series prior to 1981 was estimated by annual mean $\mathrm{N}-\mathrm{NO}_{3}$ measurements between the Danube discharge zone and Odessa on the Ukrainian shelf (Zaitsev et al. 2006). The Ukrainian data (see Fig. 2 b) provided low $\mathrm{N}-\mathrm{NO}_{3}$ values during the pre-eutrophication phase (before 1970) and increasing $\mathrm{N}-\mathrm{NO}_{3}$ concentrations during the subsequent transition to the eutrophication phase (the 1970s).

Table 1. Parameters studied, their periods of availability in the Ukrainian, Romanian and Bulgarian shelves, and the data sources. $\mathrm{X}$ : no data available

\begin{tabular}{|c|c|c|c|c|}
\hline Parameter & Ukraine & $\begin{array}{l}\text { Region - } \\
\text { Romania }\end{array}$ & Bulgaria & Source \\
\hline SST & $\begin{array}{c}\text { Odessa } \\
1960-1994\end{array}$ & $\begin{array}{l}\text { Constanta } \\
1980-2005\end{array}$ & $\mathrm{X}$ & $\begin{array}{l}\text { Belevich \& Orlova (1997) } \\
\text { Cociasu et al. (2008) }\end{array}$ \\
\hline DIN & $\begin{array}{l}\text { West coast } \\
1968-1981\end{array}$ & $\begin{array}{l}\text { Constanta } \\
1980-2005\end{array}$ & $\mathrm{X}$ & $\begin{array}{l}\text { Cociasu et al. (2008) } \\
\text { Zaitsev et al. (2006) }\end{array}$ \\
\hline $\mathrm{P}-\mathrm{PO}_{4}$ & $\begin{array}{l}\text { West coast } \\
1974-2005\end{array}$ & $\mathrm{X}$ & $\mathrm{X}$ & Loyeva et al. (2006) \\
\hline $\mathrm{SiO}_{4}$ & $\mathrm{X}$ & $\begin{array}{l}\text { Constanta } \\
1959-2005\end{array}$ & $\mathrm{X}$ & Cociasu et al. (2008) \\
\hline Phytoplankton & $\begin{array}{l}\text { West coast } \\
1954-2005\end{array}$ & $\begin{array}{l}\text { Constanta } \\
1983-2005\end{array}$ & $\begin{array}{c}\text { Galata } \\
1961-2005\end{array}$ & Nesterova et al. (2008) \\
\hline Bacterioplankton & $\begin{array}{l}\text { West coast } \\
1979-2008\end{array}$ & $\mathrm{X}$ & $\begin{array}{c}\text { Shelf } \\
\text { 1991-2003 }\end{array}$ & $\begin{array}{l}\text { Kovalova et al. (2008) } \\
\text { Oguz et al. (2008b) }\end{array}$ \\
\hline Trophic zooplankton & $\begin{array}{l}\text { West coast } \\
1954-2004\end{array}$ & $\begin{array}{c}\text { Shelf } \\
1984-2007\end{array}$ & $\begin{array}{c}\text { Shelf } \\
1959-2005\end{array}$ & $\begin{array}{l}\text { Grishin et al. (2007) } \\
\text { Shiganova et al. (2008) }\end{array}$ \\
\hline Noctiluca scintillans & $\begin{array}{l}\text { West coast } \\
1967-2006\end{array}$ & $\mathrm{X}$ & $\begin{array}{c}\text { Shelf } \\
1967-2006\end{array}$ & Shiganova et al. (2008) \\
\hline Aurelia aurita & $\begin{array}{c}\text { Shelf } \\
1965-2001\end{array}$ & $\mathrm{X}$ & $\mathrm{X}$ & $\begin{array}{l}\text { Grishin et al. (2007) } \\
\text { Shiganova et al. (2008) }\end{array}$ \\
\hline Mnemiopsis leidyi & $\begin{array}{c}\text { Shelf } \\
1988-2005\end{array}$ & $\mathrm{X}$ & $\mathrm{X}$ & $\begin{array}{l}\text { Grishin et al. (2007) } \\
\text { Shiganova et al. (2008) }\end{array}$ \\
\hline Fish & $\mathrm{X}$ & $\begin{array}{c}\text { Shelf } \\
1960-2006\end{array}$ & $\mathrm{X}$ & $\begin{array}{l}\text { Navodaru et al. (2001) } \\
\text { Maximov and Staicu (2008) } \\
\text { Zahaira et al. (2008) }\end{array}$ \\
\hline
\end{tabular}


The Constanta phosphorus $\left(\mathrm{P}-\mathrm{PO}_{4}\right)$ time series data were contaminated by the contribution from local waste water treatment plants near the measurement site, and therefore are not representative of typical conditions. An alternative data set provided by seasonal measurements at several stations along the western Ukrainian coastal waters (Loyeva et al. 2006) produced approximately half the concentration of $\mathrm{P}-\mathrm{PO}_{4}$ but similar long-term temporal changes.

Long-term annual mean phytoplankton biomass data were available from the Constanta monitoring site (Romania) starting in 1984, and from the Galata monitoring site (Bulgaria) in 1961 (Nesterova et al. 2008). For the Ukrainian shelf, phytoplankton data have been reported as multi-annual averages starting in the early 1970s (Nesterova et al. 2008). Although multi-annual averaging appreciably levels inter-annual variability, the analysis is able to capture transitions between ecological states.

Annual mean trophic zooplankton biomass was available for the Ukrainian and Bulgarian shelves between 1960 and 2005 and the Romanian shelf between 1984 and 2007. Here, trophic zooplankton is referred to as all non-gelatinous and non-opportunistic species groups (e.g. Copepoda, Cladocera, microzooplankton, meroplankton) that serve as the main prey for higher predators. The long-term annual mean jellyfish Aurelia aurita and ctenophore Mnemiopsis leidyi biomass data were provided as averages of the seasonal measurements only for the Ukrainian shelf at stations shown in Fig. 1.

Noctiluca scintillans has been a dominant species of the food web in the Black Sea. This well-known red tide organism is a voracious predator of phytoplankton, bacteria, detritus, microzooplankton, heterotrophic nanoflagellates, eggs and naupliar stages of copepods (Fock \& Greve 2002, Umani et al. 2004). It has almost no predator (except Sagitta setosa and a limited number of copepod species) due to its low carbon and high ammonia content. Annual mean N. scintillans biomass data were available for the Bulgarian and Ukrainian coasts between 1967 and 2006. Data for the Ukrainian coast were available as multi-annual mean values after 1990 . Bulgarian data, which were originally expressed as abundance, were converted to biomass by multiplying the abundance values by the average wet weight of $0.08 \mathrm{~g}$ (Fonda Umani et al. 2004).

The lower trophic level food web data were complemented by the long-term total capture production (the sum of fish, molluscs, crustaceans, and aquatic plants harvested or collected for commercial, industrial, and subsistence use excluding aquaculture production), total fish catch of freshwater, migratory and marine species, as well as piscivore catches on the Romanian shelf (Navodaru et al. 2001, Maximov \& Staicu 2008).
The Ukrainian and Bulgarian catch data were not included in the analysis because they were not as comprehensive as the Romanian data. However, the data available followed similar temporal changes (Panayotova \& Mikhailov 2006, Shlyakhov \& Charova 2006).

\section{RESULTS}

\section{Long-term variations of major ecosystem properties}

Danube discharge rate and SST. The Danube River annual discharge rate and the annual mean SST measured at Odessa and Constanta correlated positively $\left(r^{2}=0.63 ; p<0.005\right)$ (Fig. 2a), presumably because they were both regulated by the North Atlantic Oscillation (NAO) (Oguz et al. 2006). They had increasing decadal trends during the 1970s and 1990s but a decreasing trend in the 1980s. These trends were accompanied by strong interannual variation. Their concurrent strong decline in 1993 is of particular importance for the current study.

Dissolved inorganic nutrient concentrations. The most conspicuous feature of $\mathrm{SiO}_{4}$ concentration was a 4 -fold decline from $60 \mu \mathrm{M}$ in $1970-1975$ to $15 \mu \mathrm{M}$ in 1980-1985 (Fig. 2b), which has been explained by its retention in the Iron Gate 1 and 2 reservoirs (Humborg et al. 2000). The latter value remained unchanged during the last 2 decades except for some sub-decadal scale fluctuations. The other inorganic nutrients varied differently; DIN increased from less than 5 to $\sim 15 \mu \mathrm{M}$, and $\mathrm{P}_{-} \mathrm{PO}_{4}$ from less than 1 to $4 \mu \mathrm{M}$ before and after the $1970 \mathrm{~s}$, respectively. DIN concentration remained around $13 \mu \mathrm{M}$ in the 1980s and 1990s, whereas $\mathrm{P}_{-} \mathrm{PO}_{4}$ concentration decreased abruptly from $4 \mu \mathrm{M}$ in 1991 to $\sim 0.5 \mu \mathrm{M}$ in 1992-1993 and remained below $1 \mu \mathrm{M}$ afterward. Thus the DIN: $\mathrm{PO}_{4}$ ratio changed roughly from less than 10 in the 1980 s to greater than 20 in the 1990s, indicating a shift from nitrogen to phosphorus limitation.

We estimated the most limiting nutrient of phytoplankton production by computing the Monod-type nutrient uptake functions, $f_{\mathrm{x}}=X /\left(K_{\mathrm{x}}+X\right)$, where $X$ denotes the specific nutrient concentration and $K_{\mathrm{x}}$ refers to the corresponding half saturation constant. In this approach, the lowest $f_{\mathrm{x}}$ represents the most limiting nutrient. For half saturation constants of $3 \mu \mathrm{M}$ for DIN and $\mathrm{SiO}_{4}$, and $0.2 \mu \mathrm{M}$ for $\mathrm{PO}_{4}$ (Lancelot et al. 2002, Philippart et al. 2007), DIN was the most limiting nutrient prior to 1990 (Fig. 2c). It imposed a strong limitation $(\sim 0.5$ to 0.6$)$ during the pristine state, but fluctuated around 0.80 from the mid-1970s to the present. Phosphate limitation was comparable (0.80 to 0.95) with DIN prior to 1991, but decreased abruptly to 0.5 in 1992-1993, which limited phytoplankton growth. The 
phosphorus limitation prevailed with some relaxation (up to 0.75) during 1995-2002 at times of higher Danube discharge rate and it declined (to $~ 0.5$ ) during the low Danube discharge period of 2003-2004. The analysis was valid regardless of the exact choices of
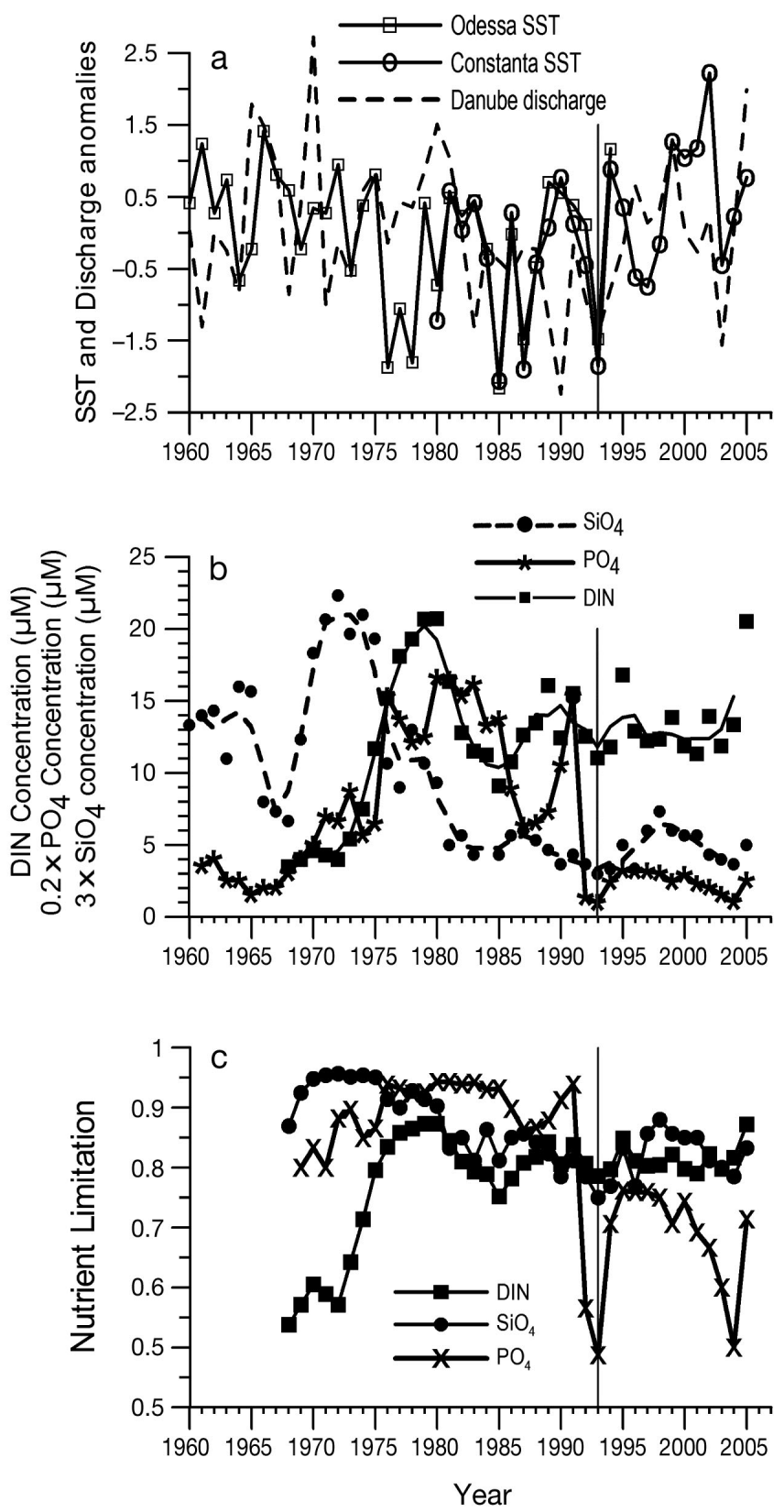

Fig. 2. Time series of annual mean (a) standardized Danube discharge anomaly at Ceatal Ismail (broken line), and standardized sea surface temperature (SST) anomaly measured near Odessa $(\square)$ for 1960-1994 and Constanta (O) for 1980-2005; (b) dissolved inorganic nitrogen (DIN) concentration $(\mathbf{\square})$, phosphate $\left(\mathrm{P}-\mathrm{PO}_{4}\right)$ concentration $(*)$ and silicate $\left(\mathrm{SiO}_{4}\right)$ concentration $(\bullet)$ (symbols denote the original data and lines represent their 3 point moving averages); (c) nutrient limitation functions computed according to the Monoduptake formula for DIN ( $\mathbf{\square}), \mathrm{P}_{-} \mathrm{PO}_{4}(\mathbf{X})$ and $\mathrm{SiO}_{4}(\bullet)$ half saturation constants. The silicate limitation appeared to be most critical during the 1980 s, as suggested by the observation of dinoflagellate-dominated phytoplankton production (Nesterova et al. 2008).

Phytoplankton. Annual mean phytoplankton biomass for the Ukrainian, Romanian and Bulgarian shelves varied similarly (Fig. 3a), consistent with those of nutrient concentrations and nutrient limitation functions. The 2-fold greater biomass in the Ukrainian shelf reflected more intense phytoplankton production on the northern side of the Danube discharge zone. Following an order of magnitude rise during the first half of 1970s, phytoplankton biomass continued to increase
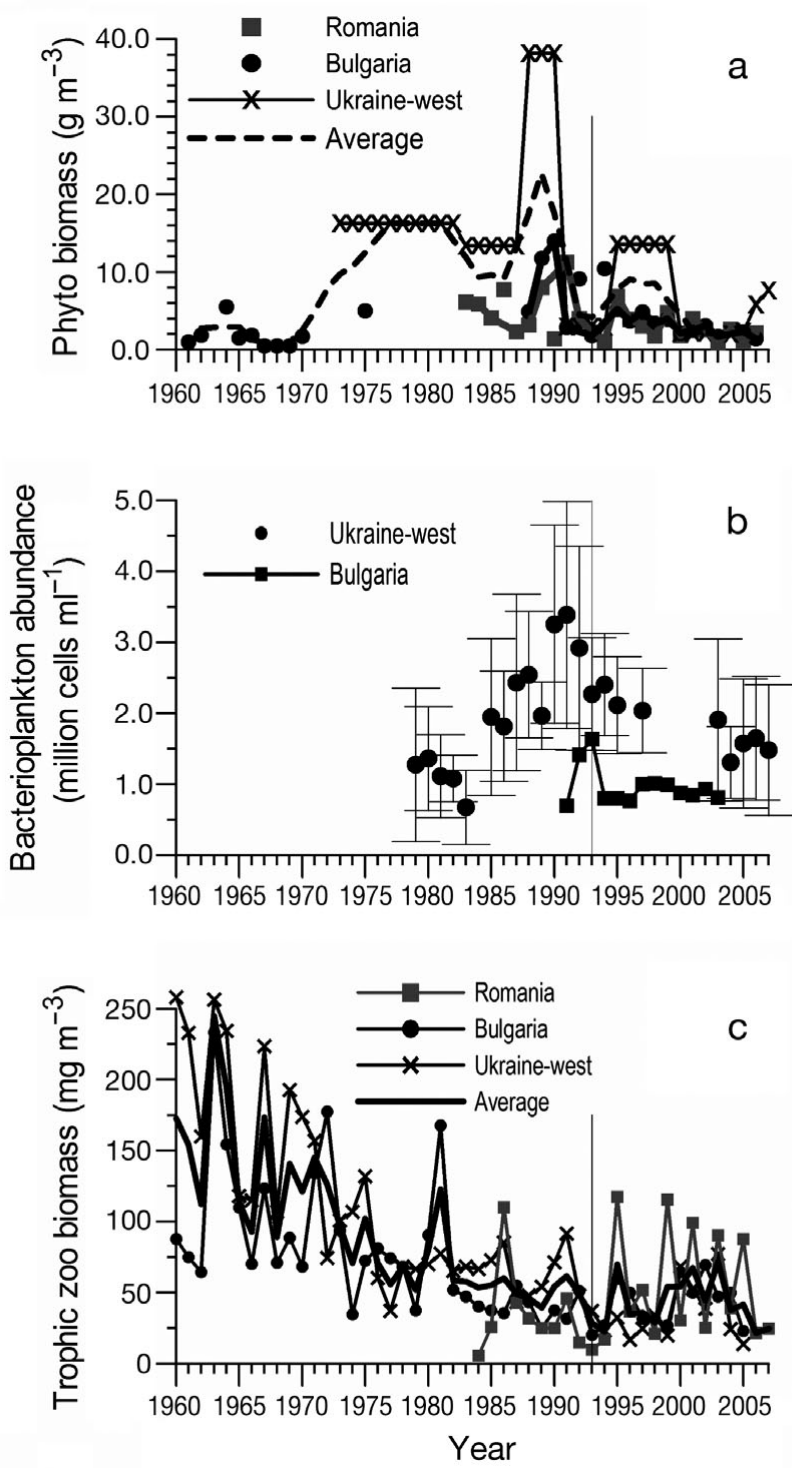

Fig. 3. Time series of the annual mean (a) phytoplankton biomass, (b) bacterioplankton abundance, (c) trophic zooplankton biomass as the averages of all available measurements in Bulgarian, Romanian and Ukrainian shelf areas (smoothed by the 3 point moving average) 
at the end of 1980s, but decreased to low values $(<3 \mathrm{~g}$ $\mathrm{m}^{-3}$ ) in 1992-1993. Whilst the increase coincided with the population rise of Mnemiopsis and its grazing impact on lower trophic levels, the decrease occurred simultaneously with $\mathrm{PO}_{4}$ limitation (Fig. 2c). The biomass in the Ukrainian shelf increased to more than $10 \mathrm{~g} \mathrm{~m}^{-3}$ during the second half of the 1990s, but diminished below $5 \mathrm{~g} \mathrm{~m}^{-3}$ afterwards. However, phytoplankton biomass in the Bulgarian and Romanian shelves remained persistently below $5 \mathrm{~g} \mathrm{~m}^{-3}$ after 1993 because of a substantial decline in the level and frequency of blooms.

The average of these 3 data sets, shown by the bold discontinuous line in Fig. 3a, closely resembled the form of the nutrient limitation function. The transition to the high biomass regime in the 1970s was supported by the 2 -fold increase in the DIN limitation function, whereas the transition to the low biomass regime in 1992-1993 coincided with the 2-fold decrease in the P$\mathrm{PO}_{4}$ limitation function (Fig. 2c).

Bacterioplankton. Bacterioplankton abundance over $10^{6} \mathrm{cells} \mathrm{ml}^{-1}$ in the Ukrainian shelf indicated an active microbial loop associated with high biological production in the 1980s (Fig. 3b). Its rise to about $3 \times 10^{6}$ cells $\mathrm{ml}^{-1}$ at the end of 1980s and the subsequent decline to $2 \times 10^{6}$ cells ml $^{-1}$ in 1993 were similar to phytoplankton biomass changes and were possibly associated with reduced bottom-up resource supply and weak nutrient recycling. Bacterioplankton abundance also decreased sharply on the Bulgarian shelf (Fig. 3b).

Zooplankton. High interannual variability was characteristic of zooplankton biomass (Fig. 3c), probably due to complex prey-predator interactions and food competition. Nevertheless, 2 decreasing trends were superimposed on these fluctuations. The first one was stronger and encompassed the beginning of 1960s (150 to $\left.250 \mathrm{mg} \mathrm{m}^{-3}\right)$ to the mid-1970s $\left(\sim 50 \mathrm{mg} \mathrm{m}^{-3}\right)$, and was followed by the second one to a minimum $(\sim 25 \mathrm{mg}$ $\mathrm{m}^{-3}$ ) in 1992-1994. During the post-eutrophication period after 1993, biomass also fluctuated annually, but it remained below $50 \mathrm{mg} \mathrm{m}^{-3}$ which was indicative of continuing degraded ecosystem conditions as opposed to the high biomass ( 150 to $250 \mathrm{mg} \mathrm{m}^{-3}$ ) regime of the pristine state.

Opportunistic species, Noctiluca scintillans. Both the Bulgarian and Ukrainian data sets suggested low Noctiluca biomass $\left(\sim 100 \mathrm{mg} \mathrm{m}^{-3}\right)$ in the pristine period (Fig. 4a). However, it rapidly increased by an order of magnitude to $>1000 \mathrm{mg} \mathrm{m}^{-3}$ at times of high phytoplankton biomass in the second half of the 1970s (Fig. 3a). Starting in 1980, relatively high biomass coincided with cold SST years and vice versa for the warm years. Accordingly, 3 specific cold years, 1985, 1993, 2003, had the highest biomass $\left(\sim 1000 \mathrm{mg} \mathrm{m}^{-3}\right)$, whereas warm years (e.g. the mid-1990s) were charac-
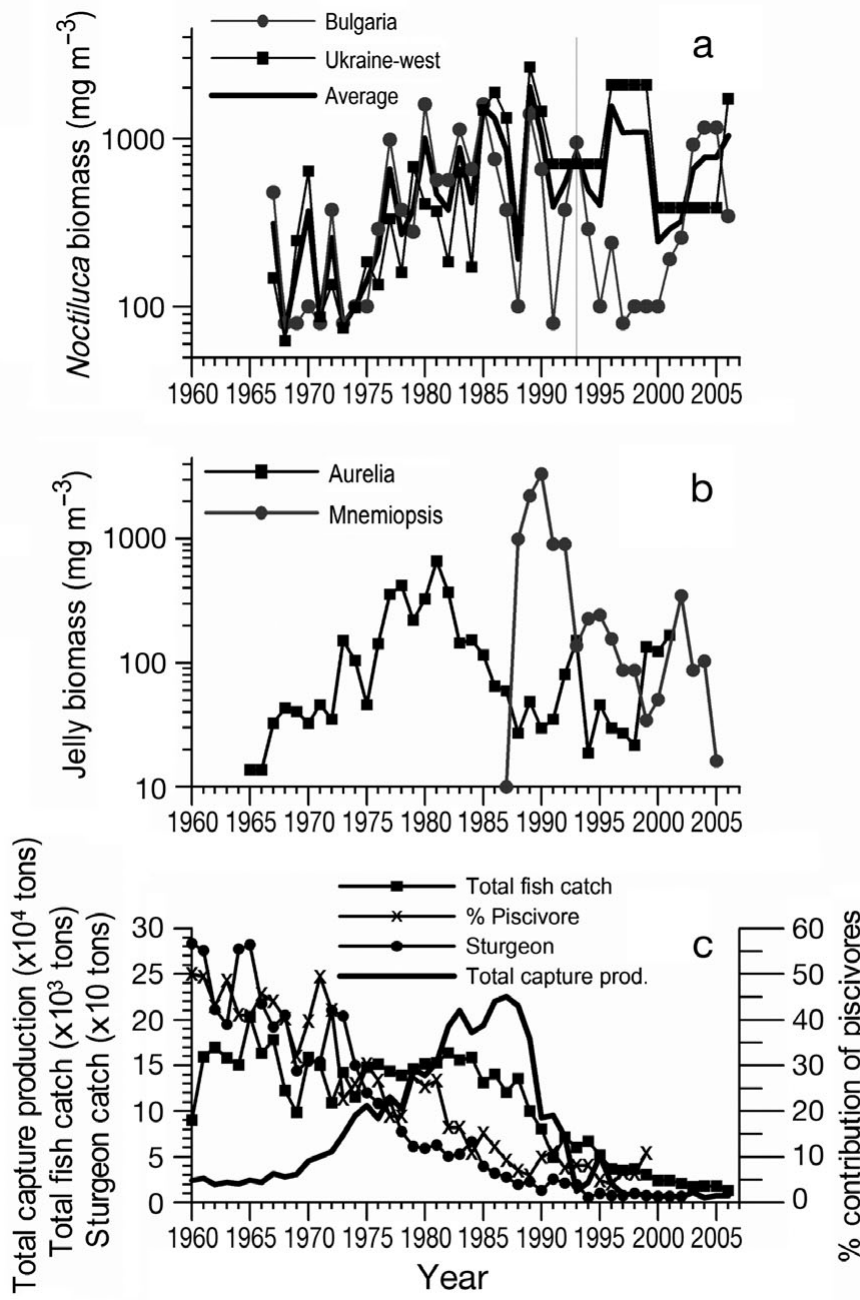

Fig. 4. Time series of the annual mean biomass of (a) Noctiluca scintillans, (b) gelatinous zooplankton species Aurelia aurita and Mnemiopsis leidyi, and (c) total fish catch, sturgeon catch, percent piscivore contribution to the total fish catch, and total capture production in the Romanian sector of NWS taken from http://earthtrends.wri.org/pdf_library/ country_profiles/

terized by lower biomass $\left(\sim 100 \mathrm{mg} \mathrm{m}^{-3}\right)$ (except in 1989-1990). Multi-annual averaging of the Ukrainian data masked interannual variability after 1990, though blooms were apparent during the post-eutrophication period.

Gelatinous species, Aurelia aurita and Mnemiopsis leidyi. A. aurita biomass increased from less than 40 $\mathrm{mg} \mathrm{m}^{-3}$ in the pristine phase to $1000 \mathrm{mg} \mathrm{m}^{-3}$ in 1980 (Fig. 4b). This increase tended to follow nutrient enrichment of the system. However, the subsequent declining trend down to $\sim 100 \mathrm{mg} \mathrm{m}^{-3}$ in 1988 was coincident with and possibly caused by the prevailing cold climatic conditions of the 1980s (Shiganova et al. 2008). Biomass of the ctenophore $M$. leidyi increased dramatically to $3000 \mathrm{mg} \mathrm{m}^{-3}$ in 1989-1990 (Fig. 4b). Its bio- 
mass was maintained at $\sim 1000 \mathrm{mg} \mathrm{m}^{-3}$ for another $2 \mathrm{yr}$ (1991-1992) and then decreased abruptly to $100 \mathrm{mg}$ $\mathrm{m}^{-3}$ in 1993, when planktonic systems collapsed. Mnemiopsis biomass recovered briefly during 1994-1995, but declined during 1996-1998, coincident with the respective warming and cooling phases (Fig. 2a). The subsequent decrease in 1999-2000 was likely related to predation by the new alien species Beroe ovata (Kamburska et al. 2006). Moreover, Aurelia biomass decreased considerably at the times of high Mnemiopsis biomass. In contrast, when Mnemiopsis biomass was low, Aurelia increased in biomass to as high as $300 \mathrm{mg} \mathrm{m}^{-3}$ (Fig. 4b).

Fish and marine living resources. The total capture production of marine living resources in Romanian coastal waters decreased by an order of magnitude in 1989-1992, and this low production regime prevailed afterward (Fig. 4c). Similarly, the total fish catch de-
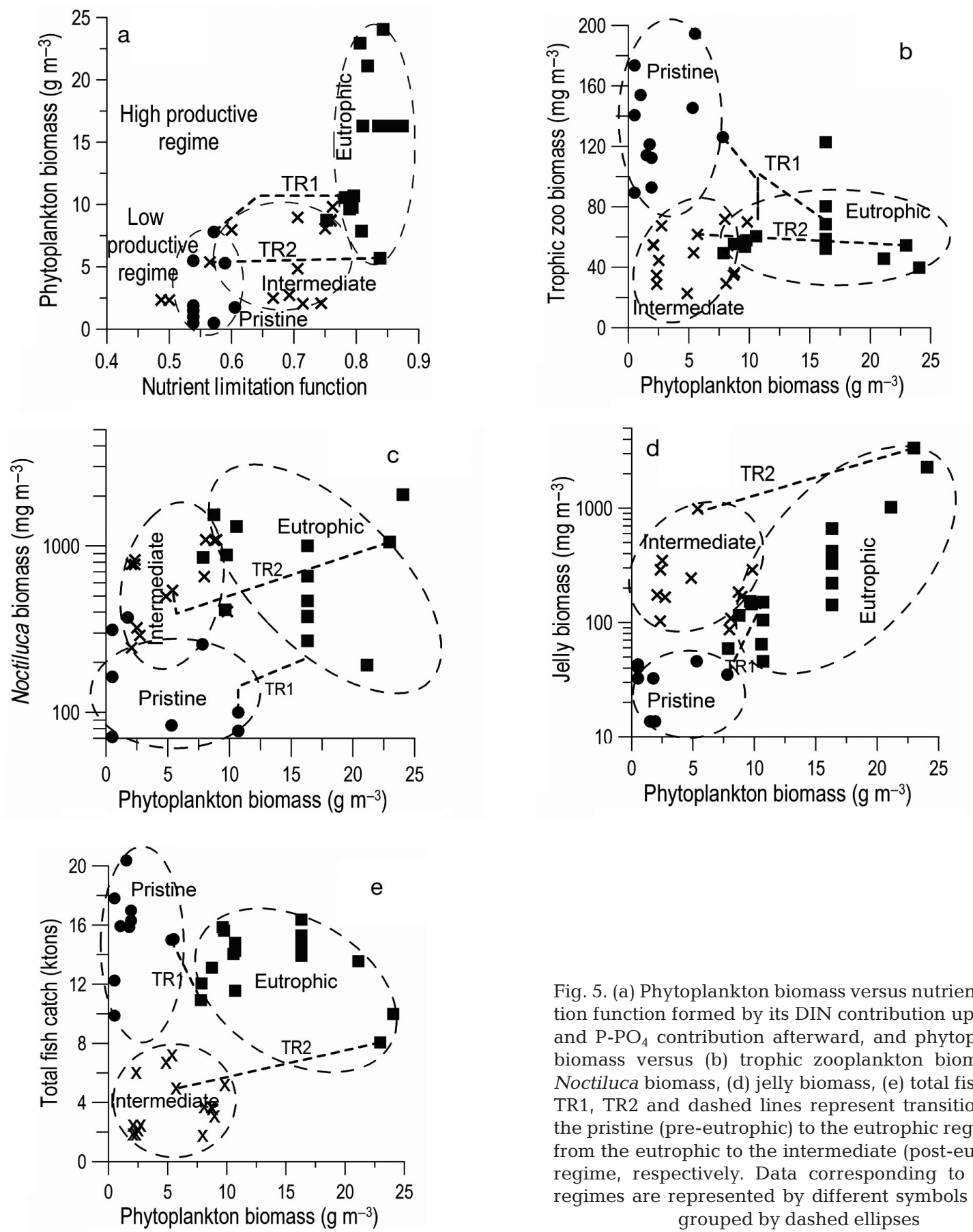

Fig. 5. (a) Phytoplankton biomass versus nutrient limitation function formed by its DIN contribution up to 1992 and $\mathrm{P}_{-} \mathrm{PO}_{4}$ contribution afterward, and phytoplankton biomass versus (b) trophic zooplankton biomass, (c) Noctiluca biomass, (d) jelly biomass, (e) total fish catch. TR1, TR2 and dashed lines represent transitions from the pristine (pre-eutrophic) to the eutrophic regime and from the eutrophic to the intermediate (post-eutrophic) regime, respectively. Data corresponding to these 3 regimes are represented by different symbols and are grouped by dashed ellipses 
clined sharply to less than 6000 tons during 1988-1991 from approximately 15000 tons during 1960-1985. It then further declined to $\sim 3000$ tons during the rest of 1990s. More importantly, piscivorous fish catch of high economical value constituted almost $50 \%$ of the total fish catch prior to 1970 , but decreased to $25 \%$ in the early 1980s and even more in the early 1990s due to over-exploitation. These low catch levels persisted during the post-eutrophication phase. The commercial catch of sturgeon also declined without subsequent recovery. The situation was slightly better in the rest of the Black Sea where the small-pelagic fish catch (mostly anchovy) achieved a partial recovery to its level in the mid-1970s (Shlyakhov \& Daskalov 2008).

\section{Alternative states and regime shifts}

Fig. 5a displays phytoplankton biomass versus the nutrient limitation function (NLF), which is formed by the contribution of DIN up to 1992 and $\mathrm{P}_{-} \mathrm{PO}_{4}$ afterward (Fig. 2c). The pre-eutrophication phase prior to 1970 and the post-eutrophication phase after 1993 represented the 2 'low nutrient availability and low phytoplankton biomass' regimes with biomass less than $8 \mathrm{~g}$ $\mathrm{m}^{-3}$. In Fig. 5a, these 2 phases are referred to as the 'pristine' and the 'intermediate' states, respectively, and differ from the 'high phytoplankton biomass and high nutrient availability' regime $\left(>10 \mathrm{~g} \mathrm{~m}^{-3}\right)$ of the eutrophic state.

Phytoplankton biomass is plotted against zooplankton biomass in Fig. 5b, Noctiluca and jelly biomass in Fig. 5c,d, and total fish catch in Fig. 5e. Phytoplankton biomass was chosen as a state variable representing bottom-up food supply to higher trophic levels. These plots demonstrate 3 different states of the ecosystem: (1) zooplankton- and piscivorous-dominated state prior to 1970 (labeled 'pristine'), (2) phytoplankton, Noctiluca, jelly and planktivorous-fish dominated state (labeled 'eutrophic'), and (3) Noctiluca and jelly-dominated state during 1993-2005 (labeled 'intermediate'). TR1 and TR2 link the eutrophic state to the former pristine and the latter intermediate states, respectively. All these plots consistently classified the pristine and intermediate states as 2 alternative states of the lower trophic food web system for phytoplankton biomass below an apparent threshold of $10 \mathrm{~g} \mathrm{~m}^{-3}$.

Fig. 6. Trophic zooplankton biomass versus (a) Noctiluca biomass, (b) jelly biomass, (c) total fish catch, and (d) jelly biomass versus total fish catch distributions. Lines connect data for consecutive years. Data corresponding to the pristine, eutrophic and intermediate regimes are represented by different sysmbols and are grouped by dashed ellipses
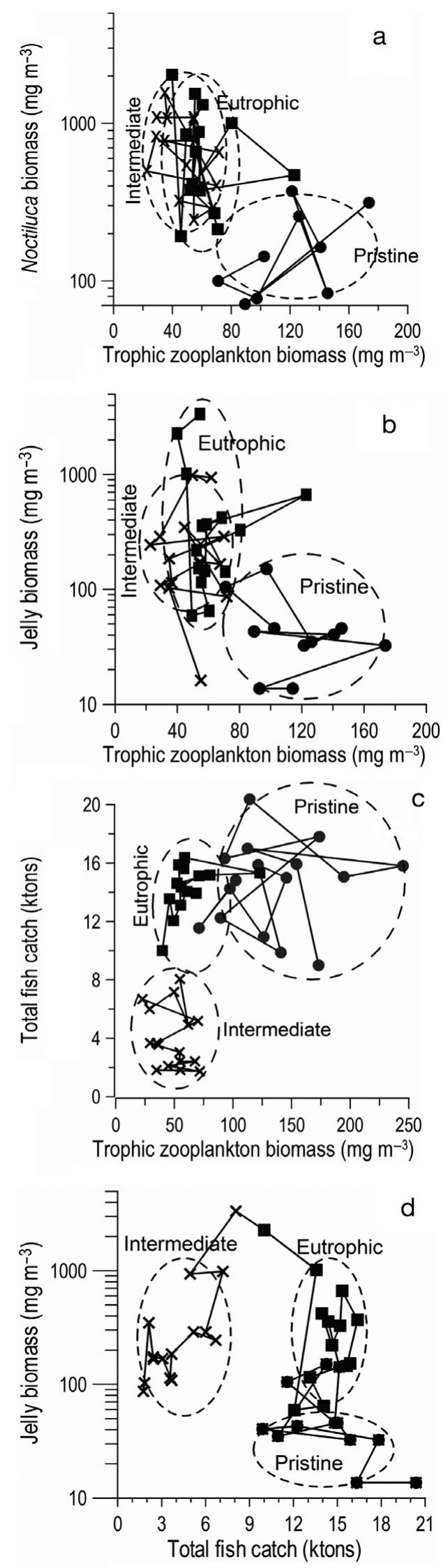
The pristine state was further characterized by high zooplankton biomass and fish catch, and low Noctiluca and jelly biomass (Fig. 6a-c). In contrast, the posteutrophication phase was associated with low zooplankton biomass and fish catch, and moderate Noctiluca and jelly biomass. The total fish catch versus jelly biomass plot (Fig. 6d) identified the pristine state as a fish-dominated system and the intermediate state as a jelly-dominated system.

\section{DISCUSSION}

A long-term data set was used to elucidate abrupt ecological changes from high to low production along the northwestern Black Sea in the early 1990s. We assessed whether the prevailing low production state could be classified as recovery, or whether it merely reflects a different reorganization of the degraded food web structure at relatively low resource conditions.

Patterns in the long-term data were indicative of 3 alternative states in the NWS ecosystem, comprising a low production system before 1970, a highly productive eutrophic system during the 1980 s, and a relatively low production intermediate system after the early 1990s (Fig. 7). The low production system before 1970 was N-limited, and diatom-based phytoplankton production was mainly channeled through mesozoo-
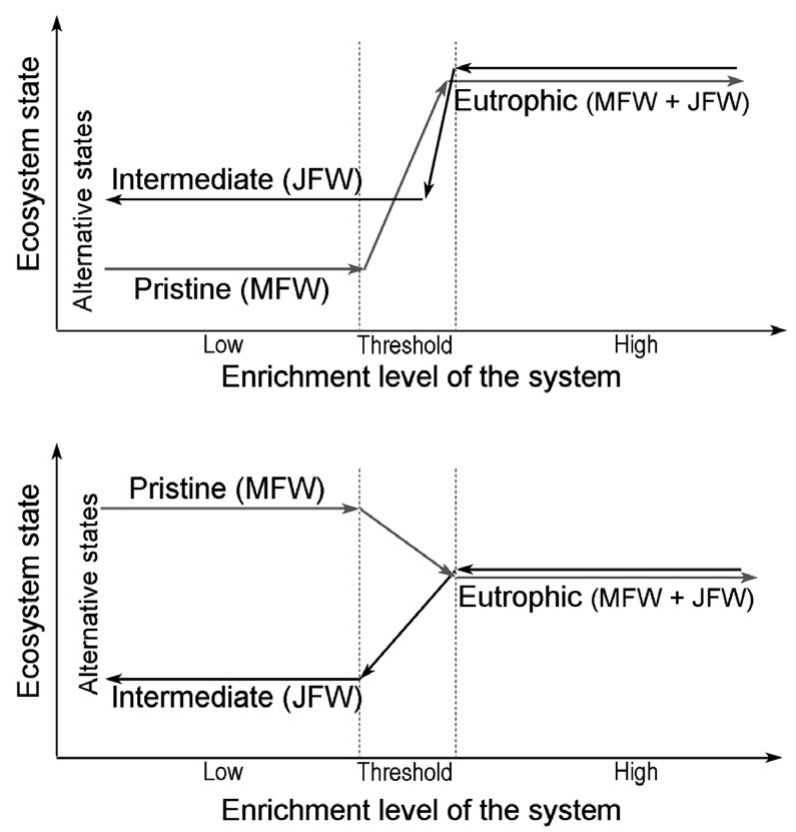

Fig. 7. Schematic representation of the 3 distinct ecosystem states for different properties of the ecosystem with respect to changing nutrient enrichment of the system. MFW and JFW denote the muscular and jelly food webs, respectively. The upper panel applies to Noctiluca and Aurelia, and the lower panel to trophic zooplankton and total fish catch plankton (copepods and cladocerans) to planktivorous fish (small pelagics) and finally to piscivores. This system is hereinafter referred to as a 'muscle food web (MFW)' (cf. Sommer et al. 2002) characterized by high ecotrophic efficiency. This state is characterized by high piscivore and zooplankton biomass, and low biomass of small pelagics and phytoplankton biomass, possibly due to a trophic cascade. The heterotrophic dinoflagellate Noctiluca scintillans and the jellyfish Aurelia aurita were not dominant components of the food web, possibly due to a competitive disadvantage against mesozooplankton and small pelagic fish under low resource availability and to grazing of Aurelia by mackerel (Zaitsev \& Mamaev 1997).

Following overfishing of the dolphin population between 1950 and 1966, and gradual depletion of bonito, bluefish, mackerel and other piscivores in the mid-1960s and early 1970s (Daskalov et al. 2007), the MFW was simplified into 3 trophic levels. Phosphate and nitrate concentrations increased 10- and 5-fold, respectively, in the first half of the 1970 s due to anthropogenic loading. This increase supported an order of magnitude higher phytoplankton biomass, which in turn stimulated greater total capture production, including small pelagics. The growing importance of the microbial loop is inferred by the doubling of the annual mean bacterioplankton abundance. The proportion of autotrophic dinoflagellate blooms increased from $15 \%$ prior to 1970 to $60 \%$ in the 1980 s (Nesterova et al. 2008), and they were accompanied by massive blooms of the heterotrophic dinoflagellate Noctiluca scintillans and high biomass of the jellyfish Aurelia aurita. This ecotrophically inefficient 'jelly food web' (JFW) structure was presumably facilitated by a strong nanophytoplankton-protozoa link (microbial food web) together with additional food from meroplankton and mesozooplankton nauplii. We hypothesize that the nutrient enrichment and a trophic cascade favored high phytoplankton production, due to grazing pressure upon zooplankton by small pelagic fishes and jellies. In addition, Noctiluca would benefit from the high phytoplankton production. This situation constituted the eutrophic state of the ecosystem.

The second transition occurred in the early 1990s due to several concurrent events, including the proliferation of Mnemiopsis due to favorable climatic conditions and the collapse of many marine living resources, such as planktivorous fish, due to overfishing (Purcell 2005, Oguz et al. 2008a). Mnemiopsis flourished in the food web along the western coastal waters during 1989-1992 (Kamburska et al. 2006), because of its wide prey base (e.g. ciliates, copepods of various sizes, nauplii, larvae of cirripeds, bivalves, eggs and larvae of fish), and its higher growth and reproductive rates relative to Aurelia and anchovy larvae during the warmer 
Table 2. Approximate ranges of major ecosystem properties during 3 different regimes of the northwestern Black Sea. Bold characters indicate the major differences in the values of ecological properties between the post eutrophication and pristine states. DIN, dissolved inorganic nitrogen; DON, dissolved organic nitrogen

\begin{tabular}{|c|c|c|c|}
\hline Property & $\begin{array}{l}\text { Pristine } \\
(<1970)\end{array}$ & $\begin{array}{c}\text { Intense } \\
\text { eutrophication } \\
(1975-1992)\end{array}$ & $\begin{array}{c}\text { Post } \\
\text { eutrophication } \\
(1993-2005)\end{array}$ \\
\hline $\mathrm{DIN}(\mu \mathrm{M})$ & 1 & 8 & 7 \\
\hline DON $(\mu \mathrm{M})$ & 10 & 25 & 40 \\
\hline $\mathrm{SiO}_{4}(\mu \mathrm{M})$ & $35-45$ & $20-25$ & $20-25$ \\
\hline $\mathrm{PO}_{4}(\mu \mathrm{M})$ & $<2$ & $3-8$ & $<2$ \\
\hline Phytoplankton $\left(\mathrm{g} \mathrm{m}^{-3}\right)$ & $<3.0$ & $10-20$ & $\sim 5$ \\
\hline (predominating group) & (diatom) & (dinoflagellate) & (diatom + dinoflagellate) \\
\hline Bacteria (million cells $\mathrm{ml}^{-1}$ ) & $<1.0$ & $2-3$ & $1-2$ \\
\hline Trophic zooplankton $\left(\mathrm{mg} \mathrm{m}^{-3}\right)$ & 250 & $75-150$ & $50-100$ \\
\hline Noctiluca scintillans $\left(\mathrm{mg} \mathrm{m}^{-3}\right)$ & $<100$ & $>1000$ & $500-1000$ \\
\hline Aurelia+Mnemiopsis $\left(\mathrm{mg} \mathrm{m}^{-3}\right)$ & 50 & $\leq 3000$ & $<500$ \\
\hline Total capture production $\left(10^{3}\right.$ tons $)$ & 30 & $>200$ & 10 \\
\hline Total fish catch $\left(10^{3}\right.$ tons $)$ & 15 & $5-15$ & 2 \\
\hline$\%$ share of piscivores in total fish catch & $40-50$ & $30-15$ & $<10$ \\
\hline
\end{tabular}

conditions. Increases in phytoplankton biomass and bacterial abundance during the outburst phase (1989-1992) may signify a new top-down trophic cascade immediately after the collapse of planktivorous fish stocks. The early 1990s also corresponded to the collapse of the former Soviet Union and Eastern Bloc countries of the Danube catchment region (Mee et al. 2005), which likely caused a reduction in $\mathrm{P}_{-} \mathrm{PO}_{4}$ loadings due to limited fertilizer use and emissions from land-based point sources (Mee et al. 2005). The years 1992 and 1993 were 2 of the coldest of the last century, and were accompanied by some of the lowest Danube discharge rates, which probably drove the severe drop in anthropogenic $\mathrm{P}-\mathrm{PO}_{4}$ loadings (Berlinsky et al. 2006, Cociasu et al. 2008) and associated resource availability. In contrast, the decrease in DIN loading was more gradual and spanned the 1990s due to a continuing supply from soil leaching within the Danube catchment basin (Kroiss et al. 2006). As a result, nutrient limitation abruptly shifted from nitrogen to phosphorus, which then severely reduced plankton production. Zooplankton biomass was then apparently not sufficient to maintain the high Mnemiopsis abundance that developed immediately after the invasion. In addition, severe winter conditions likely introduced an adverse effect on the overwintering population and, therefore, spring and summer production (Purcell 2005, Oguz et al. 2008a).

Following the switch to a low phytoplankton biomass regime in 1993, the system maintained low biomass of bacterioplankton, zooplankton, and total marine living resources, but moderate Noctiluca and gelatinous biomass. As opposed to the diatom-dominated low biomass pristine state and the dinoflagellate-dominated eutrophic state, the recent low biomass state involved mixotrophic composition of all groups that varied interannually and regionally (Nesterova et al. 2008). Population increases of Beroe and its predation on Mnemiopsis by the end of 1990s suppressed Mnemiopsis biomass to some extent, but this was compensated by an increase in Aurelia biomass. Noting that conditions in 2005 were not appreciably different from those in 1995, this ecologically-degraded situation seems to be a quasi-stable state with interannual fluctuations. The prevailing low zooplankton biomass, low marine living resources, and moderate Noctiluca and jelly biomass are indicative of a degraded ecosystem in the form of an intermediate production state between the low production but healthy pristine state and the highly productive but degraded eutrophic state. The intermediate state is dominated by jellies and opportunistic species as an alternative to the fish-dominated healthy pristine state (Fig. 7). The current state can thus not be interpreted as 'a tendency of improvement and rehabilitation of the northwestern Black Sea shelf' as suggested recently (McQuatters-Gollop et al. 2008).

Acknowledgements. This study is a contribution to the EU 6th Framework project SESAME (contract no 036949-2), the EU 7th Framework project MEECE (contract no 036949-2), and the NATO-CLG Project 982453. We thank 2 anonymous referees and the associate editor R. N. Lipcius for their helpful comments, and M. Wand for English editing of the text.

\section{LITERATURE CITED}

Beaugrand G, Edwards M, Brander K, Luczak C, Ibanez F (2008) Causes and projections of abrupt climate-driven ecosystem shifts in the North Atlantic. Ecol Lett 11: $1157-1168$

> Belevich RR, Orlova IG (1997) Inter-annual variability of the hydrological-chemical characteristics in the north-western 
Black Sea shelf area over recent decades (1960-1990). Phys Oceanogr 8:123-134

Berlinsky N, Bogatova Y, Garkavaya G (2006). Estuary of the Danube. Hdb Env Chem 5, Part H:233-264

BSC (2008) State of the environment of the Black Sea (2001-2006/7). Oguz T (ed) The Commission on the Protection of the Black Sea Against Pollution publication, Istanbul

Choi JS, Frank KT, Petrie BD, Leggett BD (2005) Integrated ecosystem assessment of a large marine ecosystem: a case study of the evolution of the Eastern Scotian Shelf, Canada. Oceanogr Mar Biol Annu Rev 43:47-67

Cociasu A, Popa L (2005) Significant changes in Danube nutrient loads and their impact on the Romanian Black Sea coastal waters. Cercet Mar 35:25-37

Cociasu A, Lazar L, Vasiliu D (2008) New tendency in nutrient evolution from Romanian coastal waters. Cercet Mar 38: 7-23

Daskalov GM (2002) Overfishing drives a trophic cascade in the Black Sea. Mar Ecol Prog Ser 225:53-63

> Daskalov GM, Grishin AN, Rodianov S, Mihneva V (2007) Trophic cascades triggered by overfishing reveal possible mechanisms of ecosystem regime shifts. Proc Natl Acad Sci USA 104:10518-10523

deYoung B, Barange M, Beaugrand G, Harris R, Perry RI, Scheffer M, Werner F (2008) Regime shifts in marine ecosystems: detection, prediction and management. Trends Ecol Evol 23:402-409

Fock HO, Greve W (2002) Analysis and interpretation of recurrent-spatio-temporal patterns in zooplankton dynamics: a case study on Noctiluca scintillans (Dinophyceae) in the German Bight (North Sea). Mar Biol 140:59-73

GEF-UNDP (2006) Trends in nutrient loads from the Danube River and trophic status of the Black Sea. Joint Report of the GEF-UNDP Black Sea Ecosystem Recovery Project and the GEF-UNDP Danube Regional Project, Istanbul

Genkai-Kato M, Carpenter SR (2005) Eutrophication due to phosphorus recycling in relation to lake morphometry, temperature, and macrophytes. Ecology 86:210-219

Grishin A, Daskalov G, Shlyakhov V, Mihneva V (2007) Influence of gelatinous zooplankton on fish stocks in the Black Sea: analysis of biological time-series. Mar Ecolog J (Sebastopol) 6:5-24

> Hanninen J, Vuorinen I, Helminen H, Kirkkala T, Lehtila K (2000) Trends and gradients in nutrient concentrations and loading in the Archipelago Sea, Northern Baltic, in 1970-1997. Estuar Coast Shelf Sci 50:153-171

> Hare SR, Mantua NJ (2000) Empirical evidence for North Pacific regime shifts in 1977 and 1989. Prog Oceanogr 47: 103-145

Humborg C, Conley DJ, Rahm L, Wulff F, Cociasu A, Ittekkot $\mathrm{V}$ (2000) Silicon retention in river basins: far-reaching effects on biogeochemistry and aquatic food webs in coastal marine environments. Ambio 29:45-50

> Ibelings BW, Portielje R, Lammens EHRR, Noordhuis R, van den Berg MS, Joosse W, Meijer ML (2007) Resilience of alternative stable states during the recovery of shallow lakes from eutrophication: Lake Veluwe as a case study. Ecosystems 10:4-16

Kamburska L, Schrimpf W, Djavidnia S, Shiganova T, Stefanova K (2006) Addressing the ecological issue of the invasive species special focus on the ctenophore Mnemiopsis leidyi (Agassiz, 1865) in the Black Sea. European Commission, Directorate-General Joint Research Centre, Institute for Environment and Sustainability

Kideys AE (2002) Fall and rise of the Black Sea ecosystem. Science 297:1482-1484
Korotaev GK, Oguz T, Nikiforov A, Koblinsky CJ (2003) Seasonal, interannual and mesoscale variability of the Black Sea upper layer circulation derived from altimeter data. J Geophys Res 108(C4):3122. doi:10.1029/2002JC001508

Kovalova N, Medinets S, Konareva O, Medinets V (2008) Long-term changes of bacterioplankton and of chlorophyll-a as indicators of northwestern part of the Black Sea ecosystem changes in the last 30 years. In: 2nd Biannual and Black Sea scene EC project joint conference on climate change in the Black Sea - hypothesis, observations, trends, scenarios and mitigation strategy for the ecosystem. Extended abstracts, Sofia

Kroiss H, Zessner M, Lampert C (2006) daNUbs: Lessons learned for nutrient management in the Danube Basin and its relation to Black Sea euthrophication. Chem Ecol $22: 347-357$

Lancelot C, Staneva J, Van Eeckhout D, Beckers JM, Stanev E (2002) Modeling the impact of the human forcing on the ecological functioning of the northwestern Black Sea. Estuar Coast Shelf Sci 54:473-500

Loyeva I, Orlova I, Pavlenko N, Popov Yu and others (2006) Estimation of the ecological state of the north-western part of the Black Sea. In: The First Biannual Scientific Conference: Black Sea Ecosystem 2005 and Beyond. Extended abstracts, Istanbul

Lysiak-Pastuszak E, Drgas N, Piaztkowska Z (2004) Eutrophication in the Polish coastal zone: the past, present status and future scenarios. Mar Pollut Bull 49:186?195

Maximov V, Staicu N (2008) Evolution of demersal fish species catches from the Romanian marine area between 2000 and 2007. Cercet Mar 38:305-324

> McQuatters-Gollop A, Mee LD, Raitsos DE, Shapiro GI (2008) Non-linearities, regime shifts and recovery: The recent influence of climate on Black Sea chlorophyll. J Mar Syst 74:649-658

Mee LD (1992) The Black-Sea in crisis - a need for concerted international action. Ambio 21:278-286

Mee LD (2006) Reviving dead zones. Sci Am 295:78-85

Mee LD, Friedrich J, Gomoiu MT (2005) Restoring the Black Sea in times of uncertainty. Oceanography (Wash DC) 18:32-43

Möllmann C, Diekmann R, Müller-Karulis B, Kornilovs G, Plikshs M, Axe P (2009) Reorganization of a large marine ecosystem due to atmospheric and anthropogenic pressure: a discontinuous regime shift in the Central Baltic Sea. Glob Change Biol 15:1377-1393

> Navodaru I, Staras M, Sencu IC (2001) The challenge of sustainable use of the Danube Delta Fisheries, Romania. Fish Manag Ecol 8:323-332

Nesterova DA, Moncheva S, Mikaelyan A, Vershinin A and others (2008) The state of phytoplankton. In: Oguz T (ed) State of the environment of the Black Sea (2001-2006/7). The Commission on the Protection of the Black Sea Against Pollution publication, Istanbul, p 173-200

Nixon SW, Ammerman JW, Atkinson LP, Berounsky VM and others (1996) The fate of nitrogen and phosphorus at the land-sea margin of the North Atlantic Ocean. Biogeochemistry 35:141-180

$>$ Oguz T, Gilbert D (2007) Abrupt transitions of the topdown controlled Black Sea pelagic ecosystem during 1960-2000: evidence for regime shifts under strong fishery exploitation and nutrient enrichment modulated by climate-induced variations. Deep-Sea Res I 54:220-242

> Oguz T, Dippner JW, Kaymaz Z (2006) Climatic regulation of the Black Sea hydro-meteorological and ecological properties at interannual-to-decadal time scales. J Mar Syst 60:235-254 
Oguz T, Fach B, Salihoglu B (2008a) Invasion dynamics of the alien ctenophore Mnemiopsis leidyi and its impact on anchovy collapse in the Black Sea. J Plankton Res 30: 1385-1397

Oguz T, Velikova V, Kideys A (2008b) Overall assessment for the present state of Black Sea ecosystem. In: Oguz T (ed) State of the environment of the Black Sea (2001-2006/7). The Commission on the Protection of the Black Sea Against Pollution publication, Istanbul, p 417-448

Panayotova M, Mikhailov K (2006) State of most abundant pelagic fish resources along the Bulgarian Black Sea coast during the period 1970-2004. In: 1st Bilateral Scientific Conference 'Black Sea Ecosystem 2005 and Beyond', extended abstracts, Istanbul. www.blacksea-commission. org/_publ-1BSCConf.asp

Parr W, Volovik Y, Nixon S, Lipan I (2005) Improving the understanding of the Danube River impact on the status of the Black Sea. UNDP-GEF Black Sea Ecosystem Recovery Project Report to the Black Sea-Danube Technical Working Group, Istanbul

Philippart CJM, Beukema JJ, Cadée GC, Dekker R and others (2007) Impacts of nutrient reduction on coastal communities. Ecosystems 10:96-119

Purcell JE (2005) Climate effects on formations of jellyfish and ctenophore blooms: a review. J Mar Biol Assoc UK 85: 461-476

Sapojnikov VV (1992) Ecology of Black Sea coastal waters: ecology of the Black Sea coastal zone. VNIRO, Moscow (in Russian)

Scavia D, Bricker SB (2006) Coastal eutrophication assessment in the United States. Biogeochemistry 79:187-208

Shiganova T, Musaeva E, Araskievich E, Kamburska L and others (2008) The state of zoooplankton. In: Oguz T (ed) State of the environment of the Black Sea (2001-2006/7). The Commission on the Protection of the Black Sea Against Pollution publication, Istanbul, p 201-246

Shlyakhov VA, Charova I (2006) Scientific data on the state of the fisheries resources of Ukraine in the Black Sea in 1992-2005. In: 1st Bilateral Scientific Conference 'Black Sea Ecosystem 2005 and Beyond', extended abstracts, Istanbul. www.blacksea-commission.org/_publ-1BSCConf. asp

Shlyakhov VA, Daskalov GM (2008) The state of marine living resources. In: Oguz T (ed) State of the environment of the Black Sea (2001-2006/7). The Commission on the Protection of the Black Sea Against Pollution publication,

Editorial responsibility: Romuald Lipcius, Gloucester Point, Virginia, USA
Istanbul, p 321-364

Sommer U, Stibor H, Katechakis A, Sommer F, Hansen T (2002) Pelagic food web configurations at different levels of nutrient richness and their implications for the ratio fish production: primary production. Hydrobiologia 484:11-20

Sorokin YI (2002) The Black Sea. Ecology and oceanography. Backhuys Publishers, Leiden

TDA (2007) Black Sea transboundary diagnostic analysis. Programme Coordinating Unit, Global Environmental Facility Black Sea Environmental Programme publication, Istanbul

Umani S, Beran A, Parlato S, Virgilio D and others (2004) Noctiluca scintillans Macartney in the Northern Adriatic Sea: long-term dynamics, relationships with temperature and eutrophication, and role in the food web. J Plankton Res 26:545-561

Vinogradova LA, Velikova VN (1992) Long-term dynamics of the NW ecosystem of the Black Sea and its modeling. Sankt-Peterburg Publishers (in Russian)

> Weijerman M, Lindeboom H, Zuur AF (2005) Regime shifts in marine ecosystems of the North and Wadden Sea. Mar Ecol Prog Ser 298:21-39

Yankovsky AE, Lemeshko EM, Ilyin YP (2004) The influence of shelfbreak forcing on the alongshelf penetration of the Danube buoyant water, Black Sea. Cont Shelf Res 24: 1083-1098

> Yunev OA, Carstensen J, Moncheva S, Khaliulin A, Aertebjerg G, Nixon S (2007) Nutrient and phytoplankton trends on the western Black Sea shelf in response to cultural eutrophication and climate changes. Estuar Coast Shelf Sci 74:63-76

Yurkovskis A (2004) Long-term land-based and internal forcing of the nutrient state of the Gulf of Riga (Baltic Sea). J Mar Syst 50:181-197

Zahaira A and others (2008) Preliminary results regardings sturgeon breeding on the Romanian littoral. Cercet Mar 38:207-222

Zaitsev YP (1992) Recent changes in the trophic structure of the Black Sea. Fish Oceanogr 1:180-198

Zaitsev YP, Mamaev V (1997) Marine biological diversity in the Black Sea: a study of change and decline. GEF Black Sea Environmental Programme. United Nations Publications, New York

Zaitsev YP, Alexandrov BG, Minicheva GG (2006) Northwestern Black Sea: Biology and ecology. Naukova Dumka, Kiev

Submitted: June 12, 2009; Accepted: February 10, 2010

Proofs received from author(s): April 26, 2010 